\title{
Sättet att bygga fasader inom svensk polis En analys av presenterad bild jämfört med verkligt utfall
}

\author{
Af Stefan Holgersson ${ }^{1}$
}

\begin{abstract}
This study examines the ways in which the Stockholm Police Department presents its results. The image the police display corresponds badly with actual outcomes. To satisfy external expectations, the priority seems to be on creating a facade of a well-functioning organization rather than providing an accurate depiction of results. This tendency is not unique to the police. It is a strategy that can be attractive to adapt, but has several negative long term effects. Most notably, it makes it more difficult to develop good and effective police work.
\end{abstract}

\section{Inledning}

Brunsson $(1989 ; 1993)$ har funnit att presentationen av siffror ofta har en högre prioritet än verkligheten bakom siffrorna inom svensk statsförvaltning. Ydén (2008) som studerat det svenska försvaret pekar på att denna särkoppling innebär att det vidtas organisatoriska ingrepp och olika former av åtgärder som egentligen inte syftar till att göra verksamheten mer effektiv. Dessa åtgärder utgör en slags politisk strategi för att skapa ett gott intryck snarare än att komma tillrätta med problem i organisationen. Ydén framför att det leder till en ständigt växande klyfta mellan den praktik som medarbetarna anser behöva tillämpas i vardagen och den bild som ledningen vill förmedla utåt. Meyer och Rowan (1977) framför att syftet med organisatoriska förändringar ofta är att göra organisationer mer legitima i sin omgivnings ögon. I själva verket kommer införandet av dessa förändringar ofta $\mathrm{i}$ konflikt med effektiviteten, något som leder till ännu en anpassningsstrategi. Denna gång handlar det om en viktig intern strategi som går ut på att koppla isär den legitimitetsskapande verksamheten från själva verksamheten. Syftet med särkopplingen är att göra det möjligt för organisationer att bedriva sin verksamhet utan att störas av legitimitetskapande reformer. Meyer och Rowan pekar på att omorganisationer, nya ledarstilar, nya arbetssätt samt målsättningar

* Title in English: The process of building facades within the Swedish police - An analysis of the the displayed image compared to the real outcome 
och policydokument som formuleras och implementeras i organisationer ofta har och ofta måste ha ett begränsat inflytande på den faktiska verksamheten som organisationen bedriver (Meyer \& Rowan, 1977). ${ }^{2}$

Polisens verksamhet hamnar lätt i fokus i media. Polisen kan kritiseras för passivitet om man undviker att agera i en viss situation. Om istället polisen agerar kan de anklagas för att ha en alltför låg toleransnivå. Hur än polisen gör finns det risk att de utsätts för kritik. I och med att polisen lätt blir föremål för ett medialt intresse är det tilltalande om organisationen lyckas presentera att verksamheten fungerar och bedrivs effektivt. Ivarsson Westerberg (2004) kom fram till att det utförs alltfler administrativa aktiviteter inom den svenska polisen som inte i första hand har att göra med det praktiska polisarbetet. Dessa aktiviteter syftar istället till att presentera, informera och redovisa polisens verksamhet för att tillfredställa intressenter i organisationens omgivning att polisverksamheten bedrivs på ett bra sätt (Ivarsson Westeberg, 2004). Stockholmspolisen har de senaste åren lyft fram ett flertal projekt och aktiviteter som lyckade, t.ex. ungdomsråden, poliskontorsorganisationen, kontaktpolisverksamheten, hatbrottsjouren och arbetet mot den organiserade brottsligheten. Etorno och Silverman (2012) presenter i sin bok med undertiteln »Management by Manipulation« hur polisen i New York agerar för att ge sken av att verksamheten fungerar på ett visst sätt, trots att så inte är fallet. Förekommer samma strategier inom den svenska polisen? I den här artikeln är Stockholmspolisen i fokus.

\section{Metod och artikelns utformning}

Datainsamlingen till denna artikel består till stor del av information hämtade från olika dokument. Den har dock kompletterats med intervjuer och registerstudier. Viss datainsamling skedde redan år 2003, men själva studien påbörjades i realiteten i maj år 2008. Under sommaren år 2009 hade jag på grund av ett annat projekt som jag genomförde på uppdrag av Rikspolischefen möjligheter att intervjua representanter för högsta polisledningen i några län samt befattningshavare ända ner till polispersonal på fältet. Jag deltog även i det operativa arbetet i respektive myndighet. Genom detta förfaringssätt fanns det goda möjligheter att konkret studera hur information förändrades när den passerade olika hierarkiska nivåer. I många fall uppstod mycket intressanta diskussioner med högre chefer. Efter dessa samtal blev jag än mer övertygad om att slutföra den studie som hade påbörjats år 2003. Flera chefer på hög nivå beklagade sig över nuvarande kultur inom polisen, där verksamhet $\mathrm{i}$ vissa sammanhang inte presenteras på ett rättvisande sätt. Framförallt Stockholmspolisens sätt att presentera olika projekt nämndes i dessa sammanhang som ett tydligt exempel på detta. 
För att svara på forskningsfrågan undersökte jag därför ett tiotal aktiviteter eller verksamheter som Stockholmspolisen upprepade gånger har presenterat som framgångsrika, bl.a. ungdomsråden, utredningsverksamheten, länskommunscentralen, poliskontorsorganisationen, kontaktpolisverksamheten, hatbrottsjouren och arbetet mot den organiserade brottsligheten. Arbetet började med att samla in hur aktiviteter har framförts fungera i olika sammanhang. Från polisens årsredovisning till olika yttranden i media. Riktigheten i dessa yttranden analyserades med hjälp av olika former av data. Ett påstående om att personalen arbetade vid vissa tillfällen kunde t.ex. analyseras med hjälp av intervjuer och utdrag ur polisens system där arbetstider redovisas. Ett påstående om att den anmälda brottsligheten gått ned i ett visst område kunde analyseras med hjälp av uppgifter från polisens anmälningssystem.

I analysen framkom att Stockholmspolisens agerande i samtliga undersökta aktiviteter eller verksamheter uppvisade ett liknande mönster. I denna artikel kommer tre av dessa att redovisas. Det fanns olika sätt att lägga upp redovisningen på. Ett var att i ett sammanhang lyfta fram hur Stockholmspolisen presenterat olika former av verksamhet och sedan redovisa vad andra datakällor indikerar beträffande sanningshalten i dessa utsagor. Ett annat var att lyfta fram en utsaga och sedan analysera denna. Därefter lyfta fram en annan utsaga kring samma tema och enskilt analysera denna. Jag valde det senare alternativet eftersom det blev mer tydligare för en läsare för att kunna göra en bedömning av tillförlitligheten i olika yttranden. Direkt i samband med ett uttalande redovisas olika förhållanden angående hur väl presentationen av utfallet stämmer överrens med andra data. Med ett sådant upplägg blev det naturligt att istället för att i detta metodkapitel gå igenom alla källor och tillvägagångssätt, presentera dessa efterhand i artikeln.

\section{Analys av Stockholmspolisens sätt att presentera verksamhet}

Arbete mot organiserad brottslighet

Det är vanligt att polisens arbete mot den organiserade brottsligheten framställs som lyckat. Två exempel på detta är Nova-projektet och arbetet mot grupperingen Black Cobra. Möjligheten att kontrollera att polisens presentationer är rättvisande är särskilt problematiskt vad gäller den organiserade brottsligheten. Externa intressenter som media och politiker är mer eller mindre utlämnade att förlita sig på att polisen redovisar utfallet av verksamheten på ett rättvisande sätt.

Nova-projektet

Nova-projektet syftade till att minska den grova och organiserade brottsligheten i Stockholms län. Tanken var att välja ut ett antal personer som polisen skulle rikta 
in arbetet emot. Utfallet av NOVA 1 redovisades till politiker i polisstyrelsen i Stockholm. Projektet framställdes som lyckat. 96 av 149 personer uppgavs ha dömts »efter olika riktade insatser«. I 36 fall skulle påföljden ha blivit fängelse i ett år eller mer. Media upptäckte dock att av de 36 fängelsedomar som ingick i Stockholmspolisens redovisning till politikerna var 15 felaktiga: $^{3}$

- I nio fall hade brottsutredningen inletts redan innan Novaprojektet startade. Sex av dessa hade även lett till åtal eller dom.

- I ett fall blev påföljden inte fängelse i ett år, vilket polisledningen uppgett, utan endast sex månader.

- I fem fall hade utredningsarbetet gjorts av polisen på andra håll i landet.

Dåvarande länspolismästare medgav för dagstidningen som upptäckt dessa felaktigheter att domar som avkunnats före Novastarten inte borde ha ingått i redovisningen. Även dåvarande chefen för länskriminalen beklagade att enstaka äldre domar räknats med. De bägge höga cheferna försvarade dock att brott som klarats upp av andra polismyndigheter togs med i resultatredovisningen av Novaprojektet. Länspolismästaren menade att:

»Det är väl utmärkt om andra polismyndigheter kunnat hjälpa till och gripa Novapersoner. I Sverige har vi ingen konkurrens mellan olika polismyndigheter. ${ }^{4}$

I mediaartikeln framgick att det märktes en viss förvåning hos de poliser och åklagare i andra delar av landet som fick se »sina« fall på Stockholmspolisens lista över lyckade Novainsatser. En kammaråklagare i Haparanda, fick en Novaklassad 26-åring från Skarpnäck dömd för rån i Kalix, sade så här:

»Det ser inget vidare ut. Rånet löstes ju av den lokala polisen här i Norrland och hade inget med något projekt i Stockholm att göra. «"

En kommissarie vid Skånepolisen, som ledde en förundersökning där en Novaklassad 31-årig Södertäljebo greps för förberedelse till rån:

»Stockholm gjorde ingenting i vår utredning, så det verkar konstigt. « ${ }^{6}$

Nova-projektet har i olika sammanhang poängterats vara mycket lyckat och dåvarande länspolismästare har kontinuerligt hävdat att Nova-projektet allvarligt har stört den grova och organiserade brottsligheten. Stockholmspolisen har nöjt sig 
med att framföra dessa konstateranden, men inte presenterat på vilket sätt man har fastställt att NOVA allvarligt har stört den grova och organiserade brottsligheten. Brå (2009) som analyserade bl.a. Nova-projektet fann att polisens arbete haft en mycket begränsad effekt på den organiserade brottsligheten. Stockholmspolisens egen kriminalunderrätelseenhet har redovisat liknande resultat. I en rapport från kriminalunderrättelsetjänsten som genomfördes på uppdrag av styrgruppen för NOVA framfördes bl.a. att:

»Det har inte gått att mäta om projektet lett till en minskning av den grova och/eller organiserade brottsligheten. Det har heller inte gått att mäta om det lett till någon minskning av nyrekryteringen till nämnd brottslighet «. ${ }^{7}$

Vidare framförs att:

»Det faller sig naturligt att dra slutsatsen att det adhocliknande arbetssättet inte ger någon uthållighet eller effekt på de grövsta kriminella. $\ll^{8}$

Trots kriminalunderrättelsetjänstens slutsats gick polisledningen ut med budskapet att projektet varit lyckat. I Stockholmspolisens årsbok för år 2005 underströk dessutom dåvarande länspolismästaren det lyckade resultatet och ifrågasatte dagstidningarnas redovisning av projektet:

»Det råder ingen tvekan om att Carin Götblad till stor del är nöjd med resultatet i Novaprojektet, trots den kritik som redovisats av dagstidningarna och som hon tycker ger en onyanserad bild av verksamheten. - 100 av länets 149 mest aktiva kriminella, de vi inom polisen kallar NOVA-markerade, har blivit lagförda, poängterar hon. «"

Polisledningens sätt att presentera projektet ger lätt intrycket av att projektet varit lyckat vad gäller att bekämpa den grova brottsligheten i länet och att de grovt kriminella dömdes till kännbara straff som påverkade deras brottsliga aktivitet. En genomgång av brotts- och belastningsregistret för de som fanns på Nova 1listan visade att de i stor utsträckning blev lagförda för brott med lågt straffvärde. Nästan 70 procent av de Nova-markerade blev inte dömda till ett fängelsestraff under Nova-projektet. Av de som blev dömda till ett fängelsestraff fick drygt 60 procent ett fängelsestraff som understeg ett år.

När utfallet av olika NOVA-insatser har lyfts fram har även de som inte varit Nova-markerade kommit med i statistiken, t.ex:

»Facit för insatsen blev bland annat fem grova narkotikabrott och sju grova vapenbrott. $\ll^{10}$ 
»Fyra anhållna och 47 rapporterade efter NOVA-insats «. ${ }^{11}$

Av enkäter framkommer att en majoritet av de inblandade poliserna anser att personaluttaget varit överdimensionerat vid de tillfälliga insatserna och att:

»... dessa i sin tur ofta har gjorts mot fel personer, på fel platser och vid fel tidpunkter « ${ }^{12}$

Presentationer av de tillfälliga insatserna gav intrycket att arbetet mot de Novamarkerade var mer framgångsrikt än det i realiteten var. I flera sammanhang har Nova-projektet lyfts fram som lyckat med argumentet att huvuddelen av de på listan blivit lagförda och att en stor andel av dem har blivit dömda till fängelsestraff.

»... I Nova-projektet ... mot grov organiserad brottslighet togs en lista fram över 149 personer som var särskilt intressanta i det brottsbekämpande arbetet. Av dessa 149 personer lagfördes ett hundratal. En tredjedel dömdes till minst ett års fängelse, en tredjedel till kortare fängelsestraff och en tredjedel till andra påföljder. $\ll^{13}$

Ovanstående citat är ett exempel på att Stockholmspolisen fortsatte att presentera missvisande och inkorrekta siffror om NOVA 1 - även efter att media belyst att redovisningen av utfallet var felaktigt. Det är för det första lätt att misstolka citatet som att $2 / 3$ av de Novamarkerade fick någon form av fängelsestraff. För det andra så stämmer det inte att $1 / 3$ av de 100 lagförda individerna blev dömda till minst ett års fängelse. En genomgång av brotts- och belastnings-registeret visar att det inte var drygt 30, utan 17 stycken av de Nova-markerade som dömdes till minst ett års fängelse. ${ }^{14}$

Möjligheten för polisen att skönmåla verksamheten utan att det avslöjas är särskilt gynnsamt vad gäller arbetet mot den organiserade brottsligheten. Det är nämligen lätt att hänvisa till sekretess som hindrar en granskning. Just detta blev fallet för den dagstidning som ville fortsätta granskningen av Nova 1. De stoppades från att få ut de uppgifter de önskade. Vid en genomgång av brotts- och belastningregistret för de som var med på Nova-listan (Nova 1) går det att misstänka att Stockholmspolisen hade ett intresse av att stoppa en vidare granskning. En jämförelse av lagföringsstatistik mellan två perioder för personer på Nova-listan (Nova 1) visar att individerna i högre grad blev dömda till fängelsestraff (eller motsvarande) innan Nova-projektet hade startat än under Nova-projektet! 
Tabell 5: Jämförelse av lagföringsstatistik mellan två perioder för de 149 personerna på listan ${ }^{15}$

\begin{tabular}{lcc}
\hline & $\begin{array}{c}\text { Okt 2001-sept 2003 } \\
\text { (Innan Nova projektet) }\end{array}$ & $\begin{array}{c}\text { Okt 2003-sept 2005 } \\
\text { (Under Nova 1) }\end{array}$ \\
\hline $\begin{array}{l}\text { Andelen av individerna i listan vars brottslighet } \\
\text { under aktuell period resulterade i att de blev }\end{array}$ & & \\
$\begin{array}{l}\text { lagförda }{ }^{16} \\
\begin{array}{l}\text { Andelen av individerna i listan vars brottslighet } \\
\text { under aktuell period resulterade i ett fängelses- } \\
\text { traff el. motsvarande }\end{array}\end{array}$ & $75 \%$ & $80 \%$ \\
\hline
\end{tabular}

Det är viktigt att poängtera att ovanstående redovisning inte skall ses som en kritik mot själva Nova-projektet eller dess personal. Ej heller mot polisledningens initiativ att starta Nova-projektet. Det exemplet syftar att tydliggöra är den presentationsstrategi som alltmer genomsyrat Stockholmspolisens agerande.

\section{Operation Serum}

Presentationen av insatsen mot gänget Black-Cobra är ett annat exempel på hur arbetet mot den organiserade brottsligheten presenteras på ett missvisande sätt. Liksom vad gäller Nova 1 hade högsta polisledningen en aktiv roll i denna presentation. Stockholmspolisen förde ut att man bedrev ett framgångsrikt arbete mot det kriminella gänget Black Cobra. Att en person hade vittnat ledde till att två personer blev dömda till fängelsestraff. Rubrikerna i en tidning blev: »Hans avhopp knäckte gänget« och »allt fler väljer att lämna de kriminella gänget« ${ }^{18} \mathrm{I}$ artikeln uttalade länspolismästaren:

»Vi är på väg att slå ut dem.«"

För media är det svårt att kontrollera denna typ av påståenden. De måste utgå från att polisen redovisar korrekta uppgifter. När det gäller uttalandet att gänget var på väg att slås ut fanns det dock en tydlig underrättelsebild (se nedan) som pekade i en helt annan riktning. Gänget var under denna period i färd med att på allvar etablerara sig i Stockholm. Ett samarbete hade inletts med personer i södra Sverige och Danmark. Minst en medarbetare som arbetade mycket nära länspolismästaren hade en god insikt om detta förhållande. ${ }^{20}$ I nyss nämnda artikel där länspolismästaren intervjuades framkom vidare att: 
»Efter sommaren insåg Stockholmspolisen allvaret med Black cobra och man bytte taktik ... Operation Serum lanserades ... »-Vi skulle se till att snabbt få många personer med anknytning till Black Cobra dömda. Vi ville visa hur det kan gå, då blir det inte lika häftigt längre. »... 15 personer har dömts till fängelse. Ytterligare minst sju är häktade och ska åtalas inom kort. » - Vi har tryckt tillbaka dem rejält. Vi har mer än halverat dem ««" ${ }^{21}$

Vid en genomgång av brotts- och belastningsregistret visar det sig att det under operation Serum var 8 av Black Cobras medlemmar som hade blivit dömda till fängelse när uttalandet gjordes - inte 15 som det är lätt att få intrycket av. ${ }^{22} \mathrm{Vi}$ dare visar en analys att i två av dessa domar hade polisarbetet redan avslutats när operation Serum startade och i ett fall hade polisarbetet utförts av polismyndigheten i Skåne. Det blir tydligt att sättet att redovisa utfallet har klara paralleller till hur NOVA-projektet presenterades. Påståendet att grupperingen mer än halverats $i$ artikeln gav intrycket av att medlemsantalet i Black Cobra hade reducerats kraftigt på grund av insatsen Serum. Kartläggningen som polisens underrättelsetjänst gjorde i början av januari år 2010 visade att Black Cobras medlemsantal inte hade minskat under operation Serum. ${ }^{23}$ Vid en genomgång av de personer som definieras som fullvärdiga medlemmar framkom att de hade lagförts för omkring 250 brott under år 2009, varav 75 resulterade i åtalsunderlåtelse. För 90 brott hade domar avkunnats innan operation Serum startade. Operation Serum var inte ett hårt slag mot grupperingen Black Cobra. Medlemmarna lagfördes nämligen i de flesta fall för relativt lindriga brott såsom olovliga körningar (68 st) och enklare former av narkotikabrott (75 st). De stod för över hälften av de lagförda brotten under år 2009.

Återigen bör betonas att det som framkommer ovan inte skall ses som en kritik mot initiativet »Serum« eller mot personalens agerande inom detta projekt.

Exempel på liknande presentationsstrategier inom andra verksamhetsområden I samband med att hatbrottsjouren bildades lyfte länspolismästaren fram att diskrimineringsbrott har varit en mycket angelägen fråga under ett flertal år:

»Polisen i Stockholms län bedriver sedan flera år tillbaka ett offensivt arbete mot olika diskrimineringsbrott och för alla människors lika värde. $\ll^{24}$

Samtidigt som Stockholms polismyndighet redovisade sitt arbete mot hatbrott, bl.a. genom ovanstående uttalande, preskriberades ett i media uppmärksammat hatbrottsärende, vilket sedermera blev föremål för Justitieombudsmannens granskning. ${ }^{25}$ Polismyndighetens förklaring till varför det gått som det gått bestod till största delen av en hänvisning till hur bra verksamheten skulle fungera i fram- 
tiden beroende på en redan initierad förändring. Detta verkar vara en vanlig strategi för att bemöta kritik. ${ }^{26}$ I yttrandet till JO skrev City polismästardistrikt att man inrättat en jourverksamhet för utredning av hatbrott vars uppgift är att åka ut med anledning av inträffade hatbrott. Jourverksamheten hade enligt yttrandet beredskap dygnet runt.

Vid en genomgång av hatbrottsjourens arbetstider under ett halvå ${ }^{27}$ visade det sig dock att ingen av dem som ingick i hatbrottsjouren hade haft jour- eller beredskap någon gång under perioden. I juni 2008 redovisades ett utredningsuppdrag, $\mathrm{i}$ form av en rapport, vilken beställts av länspolismästaren i Stockholms län angående hatbrottsjouren. I rapporten framkom att:

»Inledningsvis fanns en tanke om att hatbrottsprojektet skulle vara en form av jour, något som har övergivits under projekttidens gång. « $^{28}$

Hatbrottsprojektet behöll dock ändelsen »jour«, trots att man varken hade eller skulle ha jourverksamhet. Den som genomförde utredningsuppdraget hade ett fokus på förändringsbehov. ${ }^{29}$ Stockholmspolisen valde att inte lyfta fram vad utredaren hade kommit fram till. Rapporten om hatbrottsjouren diariefördes inte i polisens allmänna diarium. ${ }^{30} \mathrm{Jag}$ fick kännedom om rapporten och tillgång till denna via kanaler utanför Stockholmspolisen. Att rapporten hanterades som den gjordes av Stockholmspolisen kan givetvis bero på en ren tillfällighet, men att kritik undertrycks och att handlingar hanteras på ett sätt som syftar till att minimera risken för kritik har visat sig i fler fall under studien. När handlingar har begärts ut har polisen påstått att de inte existerar ${ }^{31}$ eller att förekomster av vissa handlingar inte redovisas när ett visst område är föremål för granskning. Exempelvis i samband med att polisens brottsförebyggande verksamhet ifrågasattes ${ }^{32}$ begärde media ut uppgifter om hur mycket tid som polisen avsatte till denna verksamhet. Av svaret framgick att polisen i aktuellt distrikt avsatte 82 procent till brottsförebyggande verksamhet. Polisen hänvisade inte till den kodlista där bl.a. den brottsförebyggande verksamheten fanns definierad. Denna verksamhetskodlista hade ett eget diarienummer. Att veta att det kunde vara intressant att begära ut detta dokument krävde att man kände till dess existens. I dokumentet framgick att polisen i den brottsförebyggande verksamheten bl.a. inräknade: ${ }^{33}$

- Färdighetsträning på skjutbanan och annan vapenutbildning. Även planering av sådan träning.

- Häst- och hunddressyr.

- Utryckningsförarutbildning. 
- Utbildning av personal till LKC-operatörer.

- Befälsintroduktion

- Händelsestyrd brottsförebyggande arbete (dvs. de uppdrag inom ingripandeverksamheten där radiobilar skickas till en plats)

- Rekrytering av personal som skall arbeta vid uttryckningsenheter eller som skall arbeta som piketpoliser

I de 82 procenten inräknades således ovanstående aktiviteter. Utan att ha tillgång till denna information var det svårt att värdera de uppgifter som polisen lyfte fram angående omfattning på den brottsförebyggande verksamheten. Liknande förhållande råder beträffande hatbrottsjouren. Det gäller bl.a. Stockholmspolisens påstående att tanken med hatbrottsjouren var att poliser på utryckningsenhet skulle kunna ringa till hatbrottsjouren för att få råd eller att be hatbrottsjourens personal att åka ut och hålla förhör med personer som var inblandade. Skälet till att hatbrottsjouren skulle hålla förhör på brottsplatsen i nära anslutning till brottet uppgavs vara att målsäganden ofta anmäler brott dagen efter att det inträffat och att det då är svårare att utreda brottet. ${ }^{34}$ På hatbrottsjourens hemsida framgick att hatbrottsjouren bestod av två polispatruller som arbetar med hatbrott på heltid:

»De kontaktas direkt när ett hatbrott skett och åker till brottsplatsen för att ta upp polisanmälan och hålla förhör med alla inblandade. ${ }^{35}$

Vid en genomgång av de ärenden som personal på hatbrottsjouren var inblandade i under ett halvår ${ }^{36}$ visade det sig att personal på hatbrottsjouren inte i något fall hade hållit förhör i nära anslutning ${ }^{37}$ till brott. Utifrån det material jag ${ }^{38}$ fick tillgång till visade det sig att det tog i genomsnitt sjutton dagar från att ett brott hade inträffat till att hatbrottsjouren höll sitt första förhör i ärendet. ${ }^{39}$ Det genomsnittliga förhöret på hatbrottsjouren hölls tjugotre dagar efter brottsdatumet. ${ }^{40}$ Det bör observeras att dessa siffror inte säger hur länge det tog från att hatbrottsjouren tilldelades ett ärende till att förhör hölls, eller hur lång tid det tog från brottstillfället till att ett ärende anmäldes.

Det är inte bara förhörsdatum i förhållande till brottstid som visar att verksamhet inte fungerade på det sätt som den presenterades. Även en analys av förhörsplatser åskådliggör att Stockholmspolisens påstående om hur hatbrottsjouren arbetade inte stämde. Det var bara i knappt fem procent av förhören som det fanns angivet att de genomförts på annan plats än på polisstationen. Drygt trettiosju procent av förhören hade genomförts med person som befunnit sig på polisstation. Trettionio procent av förhören hade hållits per telefon. Beträffande 
övriga nitton procent av förhören var det oklart om det rört sig om ett telefonförhör. $^{41}$

Efter att media lyft fram ovanstående förhållanden bekräftade ansvarig på hatbrottsjouren att de inte kontaktades direkt när ett hatbrott skett. ${ }^{42}$ Ett argument som förekom som en förklaring till skillnaden mellan hur verksamheten hade presenterats och hur den i realiteten hade fungerat var att Stockholmspolisen inte hade haft resurser att uppdatera hemsidor i önskvärd omfattning. I sammanhanget finns dock skäl att nämna att så sent som i januari 2009 framfördes samma information som tidigare om hatbrottsjourens arbetssätt i en ny artikel både i tidningen Sambandet och på internet. ${ }^{43}$ Det var strax innan media avslöjade att hatbrottsjouren inte arbetade på det sätt som Stockholmspolisen hävdade. Det finns också anledning att återge hur hatbrottsjourens chef till att börja med yttrade sig i den radiointervju där det avslöjades att presentationen av hatbrottsjourens verksamhet var missvisande:

»-Så fort det kommer in en anmälan så får vi den till oss och vi åker ut och träffar målsäganden. Jag tycker att det är viktigt med kontakten med brottsoffren tidigt. " $^{44}$

När reporter under intervjun konfronterade hatbrottsjourens chef med att en genomgång av ett antal anmälningar pekar på att detta inte stämmer ändrade sig hatbrottsjourens chef:

»-Vi är idag fem personer och vi har ingen möjlighet att åka runt på alla brott. Att vi skulle ha någon form av beredskap och åka ut går inte. Vi måste vara 10-12 personer för att leva upp till det som står i projektbeskrivningen. ${ }^{45}$

Stockholmspolisen har påtalat att det typiska hatbrottet som anmäls är en misshandel med främlingsfientligt motiv som begås en helgnatt i krogmiljö eller på allmän plats. ${ }^{46}$ I myndighetens verksamhetsplan för år 2008 framgår att:

»Myndigheten har utvecklat en hatbrottsjour som bl.a. ska tjänstgöra ute och leda förundersökningar med hatbrottsmotiv vid tillfällen då hatbrott kan befaras äga rum. « ${ }^{47}$

Hatbrottsjourens personal borde med tanke på ovanstående målsättning ha tjänstgjort på helgnätter. Det påstods också att så skulle vara fallet, ${ }^{48}$ men en genomgång av jourens arbetstid under ett halvår stödjer inte uttalandet. 
Tabell 27: Hur personal på hatbrottsjouren hade förlagt sin arbetstid under ett halvår ${ }^{49}$

\begin{tabular}{lccccc}
\hline & $\begin{array}{c}\text { Måndag-fredag, Måndag- torsdag } \\
\text { dagpass } \\
\text { eller söndag } \\
\text { kvälls-/nattpass }\end{array}$ & $\begin{array}{c}\text { Lördag, söndag, } \\
\text { dagpass }\end{array}$ & $\begin{array}{c}\text { Fredag eller lördag } \\
\text { kvälls-/nattpass }\end{array}$ & $\begin{array}{c}\text { Annan } \\
\text { tjänst }\end{array}$ \\
\hline Polis 1 & $98 \%$ & $0 \%$ & $0 \%$ & $1 \%$ & $1 \%$ \\
Polis 2 & $83 \%$ & $0 \%$ & $0 \%$ & $1 \%$ & $15 \%$ \\
Polis 3 & $68 \%$ & $0 \%$ & $1 \%$ & $1 \%$ & $30 \%$ \\
Polis 4 & $95 \%$ & $1 \%$ & $3 \%$ & $1 \%$ & $0 \%$ \\
\hline
\end{tabular}

Under det halvår som studerades arbetade personalen vid hatbrottsjouren en helgnatt. Det var en fredag. De arbetade då ett pass från 19.00-04.00.$^{52}$ Under efterföljande halvår, vilket inte ingick i det datamaterial som jag fick tillgång till, känner jag till att personal på hatbrottsjouren bl.a. tjänstgjorde under pridefestivalen. Det förekom således att poliser tillhörande hatbrottsjouren ägnade sig åt yttre tjänstgöring, men att bedriva utredningsverksamhet på polisstationen under kontorstid var den huvudsakliga sysslan. Det var bara i undantagsfall som någon annan tjänstgöringstid kom ifråga.

Stockholmspolisen påtalade i en faktaruta i tidningen Sambandet att tolv procent av hatbrottsjourens ärenden hade lett till åtal. Det framkom dock att hatbrottsjouren inte bara utredde sk. hatbrott. ${ }^{53}$ Hur stor andel av de tolv procenten som avsåg andra brott än hatbrott framgick inte. Huruvida Stockholmspolisen hade nått upp till huvudmålsättningen med hatbrottsjouren - att öka antalet åtal för hatbrott redovisades inte. Stockholmspolisen framförde däremot i en annan artikel i början av 2009 att:

»Hatbrottsjouren i City polismästardistrikt startade i juni 2007 som ett projekt. Resultatet är ett rejält uppsving när det gäller antalet åtal. Nu har hatbrottsjouren blivit permanent och arbetet ska spridas i hela Stockholms län. $\ll^{54}$

Daniel Velasco på Sveriges radio efterfrågade att Stockholmspolisens skulle styrka påståendet att »Resultatet är ett rejält uppsving när det gäller antalet åtak. Det visade sig att Stockholmspolisen inte kunde styrka detta påstående. Man hade inte tagit fram någon sammanställning över skillnaden mellan antal åtal innan och under projektet. Statistik från åklagarmyndigheten beträffande brotten olaga diskriminering och hets mot folkgrupp indikerar att projektet inte varit framgångsrikt vad gäller sin huvudmålsättning - att öka antalet åtal för hatbrott. Under hat- 
brottsprojektet hamnade snittet beträffande brottet hets mot folkgrupp på 6.5 brottsmisstankar per år som ledde till åtal. Det skall jämföras med åren innan hatbrottsprojektet startade då i snitt fem brottsmisstankar per år ledde till åtal. I sammanhanget bör noteras att av de elva brottsmisstankar om hets mot folkgrupp som ledde till åtal år 2008 hade hatbrottsjouren handlagt fyra. ${ }^{55}$ När det gäller antalet redovisade ärende till åklagare för brottet hets mot folkgrupp så ökade dessa under år 2007 och år 2008. År 2008 var de fyra gånger högre jämfört med året innan, men ett stort antal av dessa förundersökningar lades ner. Förhållandet har sin förklaring i att 122 brottsmisstankar om hets mot folkgrupp avsåg samma brottstillfälle (demonstration). Det var inte hatbrottsjouren som handlade dessa brottsmisstankar. Om denna händelse tas bort från statistiken visar det sig att antalet redovisade ärenden till åklagare avseende hets mot folkgrupp har legat på ungefär samma nivå under fyra av sex år (2004, 2005, 2007 och 2008). Effekten av hatbrottsjouren verkar i det avseendet vara liten.

När det gäller brottet olaga diskriminering har resultatet försämrats under hatbrottsprojektet. $^{56}$

Året innan hatbrottsjouren startade var det fyra brottsmisstankar om olaga diskriminering som ledde till åtal. Under hatbrottsprojektets var det en brottsmisstanke om olaga diskriminering som ledde fram till åtal. Det är viktigt att denna analys inte skall uppfattas som en kritik mot att projekt har startats upp eller mot det arbete som personalen i projekteten bedriver.

Studien av Stockholmspolisens sätt att presentera verksamhet indikerar att missvisande eller felaktiga resultat mer eller mindre har blivit ett signum för polisens sätt att presentera verksamhet, t.ex. presentationer av den brottsförebyggande verksamheten, ingripande verksamheten, närpolisverksamheten, utredningsverksamheten och de särskilda satsningarna såsom ungdomsråden och poliskontoren (Se Holgersson, 2005; 2007; RiR, 2010; Holgersson, 2011; Holgersson \& Knutsson, 2012; Holgersson, 2013). Stockholms polismyndighet är inte ensam om detta förhållningssätt. Det har blivit en allt viktigare del att kommunicera rätt bild av verksamheten, vilket innebär att polisen inte i alla situationer gör sig öppen och tillgänglig (Palm \& Skogersson, 2008). Alltfler administrativa aktiviteter inom den svenska polisen syftar till att presentera, informera och redovisa polisens verksamhet för att tillfredställa intressenter i organisationens omgivning att polisverksamheten bedrivs på ett bra sätt (Ivarsson Westerberg, 2004). Brister i sättet att redovisa resultat har även uppmärksammats i andra länder, bl.a. New York polisen har utsatts för omfattande kritik (Etorna \& Silverman, 2012). 


\section{Diskussion kring konsekvenser av vald presentationsstrategi}

Medborgarnas trygghet kan öka om de uppfattar att polisen lyckas fullfölja sina uppgifter på ett bra sätt. Att presentera verksamheten som väl fungerande kan därför ha positiva effekter. Förtroende för rättsväsendet $i$ allmänhet och polisen $i$ synnerhet kan öka. Genom att presentera en god bild av verksamheten finns möjlighet att övertyga externa intressenter om att polisens verksamhet fungerar bra och organisationen kan säkerställa att resurstilldelningen inte äventyras. Verksamheten kan därigenom bli stabil och förutsägbar. Medarbetarna kan också känna en tillfredsställelse över att tillhöra en väl fungerande organisation.

Brottsförebyggande rådets nationella trygghetsundersökningar pekar på att medborgares positiva bild av polisens effektivitet sjunker kraftigt när de själva konkret får uppleva polisens arbete (Brå, 2011; 2012). Den bild som medborgare får presenterad stämmer inte överrens med deras upplevelser av hur verksamheten fungerar. Om polisen fortsätter med nuvarande presentationsstrategi finns en risk att tilliten till information som polisen lämnar bli låg. En sådan uppfattning kan vara problematisk att förändra. Skillnaden mellan hur verksamheten presenteras och hur den fungerar blir påtaglig för polispersonalen. Förhållandet är bekymmersamt när det finns ett stort värde i att dessa har en god etik och på ett ärligt sätt redovisar olika förhållanden. Denna omständighet kan påverka rättsäkerheten för medborgare på ett negativt sätt (se exempelvis Wierup, 2008 och Sundvall, 2008 som beskriver det så kallade Gotlandsärendet).

Den valda presentationsstrategin kan vara positiv på kort sikt, men riskerar att medföra avsevärda negativa konsekvenser på längre sikt vad gäller bl.a. allmänhetens förtroende för polisen. Det finns ett flertal andra problem Det är inte den enda effekten för medborgarna.

Om organisationen prioriterar att satsa resurser på enheter som bidrar till att skapa en god mediabild kan det få negativa följder för andra typer av verksamheter som kräver en långsiktighet, t.ex. arbetet mot den organiserade brottsligheten. Det finns också en risk att enheter mer eller mindre känner sig tvingade att arbeta på ett visst sätt för att nå upp till ett visst produktionsresultat. På flera andra enheter där personal intervjuats framgår att just ett fokus på kvantitativ produktionsstatistik, kallad »pinnjakt«, får negativa konsekvenser på verksamheten. Arbetsmetoder anammas för att de är effektiva för att kunna uppvisa bra produktionsresultat inte för att de har störst möjlighet att ge en effekt (se vidare Holgersson, 2007; Woxblom, Holgersson \& Dolmén, 2008; Holgersson \& Knutsson, 2011). Personalen måste ges möjligheter att tillämpa metoder som anpassas efter situationen och inte efter ett yttre tryck på att kunna uppvisa lättredovisad produktionsstatistik eller vissa resultat. Det finns annars en risk att uppgifter manipuleras (se 
exempelvis Woxblom, Holgersson \& Dolmen, 2008; Holgersson, 2011). Dessutom kan det vara kontraproduktivt för polisen att gå ut med viss information. Ett exempel på detta är före detta länspolismästaren i Östergötlands löfte om att en viss mc-klubb inte skulle vara kvar i länet innan årets slut. Efter länspolismästarens uttalande fick aktuell MC-klubb förstärkning från södra Sverige och blev starkare än innan yttrandet.

En annan fara med att framställa verksamheten som väl fungerande, trots att så inte är fallet, är att trycket på förändringar kan bli lågt. Det kan gälla behovet av förändringar i arbetsmetoder, organisationsförändringar likväl som behovet av en förändrad lagstiftning. En chef för Nova-projektet framförde att det är ett stort problem att verksamheten presenteras på ett felaktigt sätt. När arbetet mot den organiserade brottslighten ger sken av att vara framgångsrik trots att »vi bara vispar lite på ytan« blir det svårt att få till nödvändiga förändring.

Sammanfattningsvis medför Stockholmspolisens sätt att presentera verksamhet positiva effekter på kort sikt, men på längre sikt finns en stor risk att vald strategi får avsevärda negativa konsekvenser.

\section{Noter}

1. Stefan Holgersson är lektor i informatik vid Linköpings universitet och polis i Stockholm. Han disputerade år 2005 med avhandling Yrke: POLIS.

2. Se även Powell \& Dimmaggio, 1991; Meyer \& Stott, 1993; Ericsson, 1981; Brunsson, 1993; Zucker, 1977.

3. DN 2006-01-16: »Polischefer bluffade om påstådd succé«.

4. DN 2006-01-16: »Polischefer bluffade om påstådd succé«.

5. DN 2006-01-16: »Polischefer bluffade om påstådd succé«.

6. DN 2006-01-16: »Polischefer bluffade om påstådd succé«.

7. LKP KUT-rapport $61 / 2005$, sidan 4, Stockholmspolisen.

8. LKP KUT-rapport 61/2005, sidan 8. Stockholmspolisen.

9. Polismyndigheten i Stockholms län. Årsrapport (2005), sidan 5.

10. Sambandet nr 5 oktober 2007, sidan $7 » N O V A$ II mot yrkeskriminella«. I resultatredovisningen ingår sannolikt både Nova-markerade och icke Nova-markerade personer.

11. Polismyndigheten i Stockholms län. Årsrapport (2006), sidan $19 » F y$ ra anhållna och 47 rapporterade efter NOVA-insats«. I resultatredovisningen ingår sannolikt både Novamarkerade och icke Nova-markerade personer. Se även t.ex. Artikel intranet/Internet 200706-04: »Framgångsrik insats mot organiserad brottslighet«, där ett stort antal rapporterade brott finns upptagna. Det framgår inte vilka brott som avser Nova-markerade personer.

12. LKP KUT-rapport 61/2005, sidan 7. Stockholmspolisen.

13. Artikel Internet 2006-09-13: »Pressmeddelande om Nova-insatser«. http://www.newsdesk.se/ view/ pressrelease/31767 
14. Källa: Brotts- och belastningsregistret. Fyra personer i lista har avlidit och jag hade därför ej tillgång till eventuella brott de lagförts för. Statistiken avser brottsdatum och inte datum för dom.

15. Källa: Brotts och belastningsregistret. Fyra personer i lista har avlidit och jag hade därför ej tillgång till eventuella brott de lagförts för. Statistiken avser brottsdatum och inte datum för dom. Arbetssättet som beskrivs inom ramen för Nova 1 handlar i huvudsak om riktade insatser i form av trafikkontroller och krogkontroller i syfte att upptäcka om Nova-markerade individer gör sig skyldiga till brott. Av den anledningen är brottsdatum mer rättvisande att utgå ifrån för att bedöma utfallet av Nova 1. I statistiken har jag valt att inkludera brott som skett $\mathrm{i}$ andra län. Siffrorna har avrundats till närmaste heltal.

16. I huvudsak brott av ringa straffvärde.

17. t.ex sluten ungdomsvård.

18. Lokaltidningen mitt i (bl.a. Botkyrka Salem och Huddinge), första sidan. 5:e januari 2010.

19. Lokaltidningen mitt i (Botkyrka Salem). 5.e januari 2010, sidan 4.

20. Att denne medarbetare har kännedom om detta har framgått i skriftligt dokument (Underrättelseuppslag, upprättat 2009-12-11). Vid sidan av underrättelseuppslag spreds informationen internt inom Stockholmspolisen att Black Cobra (BC) verkade fortsätta att etablerare sig vid aktuell tidpunkt (då uttalandet i media skedde). Information i ett mail som skickades ut från en enhetschef som arbetade med gängkriminalitet: »Det finns oroande tecken på fortsatt BC-etablering. Norra Botkyrka, Järva och särskilt i Skarpnäck. « (GroupWise sänt 2010-0125).

21. Lokaltidningen mitt i (Botkyrka Salem). 5.e januari 2010, sidan 4.

22. Källa: Brotts- och belastningsregistret. En ytterligare person blev dömd till fängelse som ingår i underrätelsetjänstens chart över medlemmarna i Black Cobra (Upprättad: 20100126). Denna person tillhör dock ett helt annat gäng och inte Black Cobra (intervju med person på underrättelsetjänsten som har en god inblick i detta gäng).

23. Personal tillhörande underrättelsetjänsten redovisade på individnivå Black Cobras utveckling under operation Serum.

24. Artikel Intranet/Internet 2007-06-05: »Nu öppnar hatbrottsjouren«.

25. JO 2878-2007.

26. Se även JO-beslut 2672-2008; Finansdepartementet (2001).

27. Källa: Paris. Avser första halvåret 2008.

28. Hermansson (2008), sidan 13.

29. Hermansson (2008), sidan 3.

30. Det gick varken att hitta rapporten eller att den blivit diarieförd (juni 2008). Jag fick hjälp av personal som på heltid arbetar med Stockholmspolisens allmänna diarium. Sökning skedde både på författarens namn, titel på rapportc etc. Dessutom gick vi igenom information som gällde hatbrottsjourens diarieförda handlingar, utan att hitta något som tydde på att rapport diarieförts. Dokumentet avseende direktiv till rapporten fanns dock diarieförd (AA-19977564-2006, nr 49). Denna handling och andra handlingar, i vilka man kunde tänka sig att rapporten fanns diarieförd, begärdes ut. Rapporten fanns ej där.

31. Se t.ex. AA-187-6373-2009, som innehåller ett negativt besked på en begäran att få ut handlingar med motivering att handlingarna inte finns - trots att de finns.

32. 2008-08-29 (Sveriges Radio. Dagens Eko). 2008-08-30 (SverigesRadio, P1, »Listan«). 
33. AA-192-86926-07, bilaga Verksamhetskodlista för år 2008.

34. Artikel Internet 2007-07-17 »Hatbrottsjouren på plats i krogkön« http://www.polisen.se/ inter/util/nodeid $=21434 \&$ pageversion $=1 . j s p ?$ articleid $=9609514$

35. Artikel Internet »Hatbrottsjour $i$ Stockholms city« http://www.polisen.se/inter/nodeid =9659001\&pageversion=1.jsp (2009-01-15). Se även artikel Internet 2007-07-18: »Satsning mot hatbrott för fler fall till åtal«. http://www.police.se/inter/util/nodeid=21434\& pageversion=1.jsp?articleid=9623268 och 2009-01-09: »Mot diskriminering $i$ vardagen. $«$ http://www.polisen.se/inter/util/nodeid=21434\&pageversion $=1 . j s p ?$ articleid= 14335217 ; Sambandet $\mathrm{nr}$ 1, jan 2009, sidan 10-11»Arbete mot diskriminering $i$ vardagen«.

36. Förhör i ärenden (122 st ärenden) som personal på hatbrottsjouren varit inblandade i under sex månader (feb-juli 2008) begärdes ut. Förhör som inte utförts av personal på hatbrottsjouren sorterades bort. Utifrån de handlingar vi fick tillgång till visade det sig att personal på hatbrottsjouren varit förhörsledare vid 110 förhör (Förhör i de efterfrågade ärendena som genomförts av personal på hatbrottsjouren efter juli 2008 har också räknats med).

37. Inom några timmar.

38. Jag fick hjälp med att föra in uppgifter från RAR-anmälningar/Dur-Två till excel-fil (brottsdatum/tid och förhörsdatum/tid) gällande 122 ärenden som jag sedan kunde analysera.

39. Medelvärde: 16.9 dagar. Medianvärde: 9.5 dagar.

40. Medelvärde: 23.2 dagar. Medianvärde: 10 dagar.

41. Huvuuddelen av dessa nitton procent rörde sig sannolikt om telefonförhör. Det är vanligt att förhörsplats ej anges när det är fråga om ett telefonförhör. Om telefonförhör har hållits skall detta dokumenteras genom att en särskild ruta markeras i förhöret. Detta kan lätt missas.

42. Dels framkom detta vid samtal som jag hade med chef för hatbrottsjouren, dels i artikel på Internet 2009-01-26: »Kommentarer gällande Stockholmspolisens arbete med hatbrott« http://www.polisen.se/inter/util/nodeid=21434\&pageversion $=1$.jsp?articleid=14469305

43. 2009-01-09: »Mot diskriminering $i$ vardagen.« http://www.polisen.se/inter/util/nodeid $=21434$ \&pageversion=1.jsp? articleid $=14335217$; Sambandet $\mathrm{nr}$ 1, jan 2009, sidan 10-11 "Arbete mot diskriminering $i$ vardagen «.

44. Sverige radio, Ekot. 25:e januari. »Trögt polisarbete mot hatbrott.« http://www.sr.se/ ekot/artikel.asp?artikel=2588884http://mobil.sr.se/site/index.aspx?artikel=2588884\&uni tid $=83$

45. Sverige radio, Ekot. 25:e januari. »Trögt polisarbete mot hatbrott.« http://www.sr.se/ekot/ artikel.asp?artikel $=2588884 \mathrm{http}: / /$ mobil.sr.se/site/index.aspx?artikel $=2588884 \&$ unitid $=83$

46. Artikel Intranet/Internet 2007-06-04: »Nu öppnar hatbrottsjouren«.

47. Polismyndigheten i Stockholms län. Verksamhetsplan (2008), sidan $10 »$ Hatbrott«.

48. Se t.ex. artikel Internet 2007-07-17: »Hatbrottsjouren i Stockholm på plats i krogkön.« http://www.polisen.se/inter/util\%5Cnodeid=21434\&pageversion=1.jsp?articleid=9609514 och 2009-01-09: »Mot diskriminering $i$ vardagen. « http://www.polisen.se/inter/util/nodeid $=21434 \&$ pageversion=1.jsp? articleid $=14335217$; Sambandet nr 1, jan 2009, sidan 10-11 »Arbete mot diskriminering $i$ vardagen $\ll$.

49. Källa: PARIS. Avser första halvåret 2008.

50. Tjänstgöringspass som har en sluttid efter 21.00 .

51. Tjänstgöringspass som har en sluttid efter 21.00.

52. En av poliserna slutade 02.00. Källa: PARIS. 
53. Sambandet nr 1, jan 2009, sidan $11 »$ fakta Hatbrott«

54. Artikel Internet 2009-01-09: »Mot diskriminering $i$ vardagen.« http://www.polisen.se/inter/ util/nodeid $=21434 \&$ pageversion $=1$.jsp?articleid $=14335217$; Sambandet nr 1, jan 2009, sidan 10-11 »Arbete mot diskriminering $i$ vardagen «.

55. Uppgifter om handläggare hämtade från dokument gällande respektive ärende.

56. Statistik hämtad från Riksåklagaren.

\section{Referenser}

Brunsson, N. (1989). The Organization of Hypocrisy: Talk, Decision and Action in Organizations. New York.: John Wiley \& Sons

Brunsson, N. (1993). Ideas and Actions. Justification and Hypocrisy as an Alternative to Control. Accounting, Organizations and Society. Vol 18, nr 6, s 489-506.

BRÅ (2009). Polisens satsning mot organiserad brottslighet. En utvärdering av 43 projekt. Rapport 2009:19. Stockholm: Brottsförebyggande rådet.

BRÅ (2011). NTU 2010. Stockholm: Brottsförebyggande rådet.

BRÅ (2012). NTU 2011. Stockholm: Brottsförebyggande rådet.

Ericsson, R. (1981). Rules for Police Deviance i Shering, C. (red.) Organisational Police deviance, sid 83-110, Toronto: Botterworths

Eterno, A. \& Silverman, E. (2012). The Crime Numbers Game: Management by manipulation. New York: CRC Press

Holgersson, S. (2005). Yrke: POLIS - Yrkeskunskap, motivation, IT-system och andra förutsättningar för polisarbete. Linköping: Doktorsavhandling, Institutionen för datavetenskap, Linköpings universitet.

Holgersson, S. (2007). Kartläggning av svenska polisens narkotikabekämpning, Rapport 23. Stockholm: Mobilisering mot narkotika, Socialdepartementet.

Holgersson, S. (2011). Appendix till rapporten: »Polisens arbete mot narkotika«. Linköping: Linköpings universitet http://www.iei.liu.se/is/holgersson-stefan/publikationer/1.301514/ Narkotika-PM.pdf

Holgersson, S. \& Knutsson, J. (2011). Polisens arbete mot narkotika. Rikspolisstyrelsens utvärderingsfunktion. Rapport 2011:1. Stockholm: Rikspolisstyrelsen.

Holgersson, S. \& Knutsson, J. (2012). Vad gör egentligen polisen? Linköping: Linköpings universitet

Holgersson, S. (2013). Polisens sätt att presentera verksamhet. Pågående rapport. Linköping: Linköpings universitet

Ivarsson Westerberg, A. (2004). Papperspolisen. Den ökade administrationen i moderna organisationer. Doktorsavhandling. Stockholm: Handelshögskolan.

LKP (2005). LKP KUT-rapport 61/2005. Stockholm: Stockholmspolisen

Meyer, J \& Rowan, B. (1977) Institionalized organizations. Formal structure as myth and ceremony. American journal of Sociology, 83.

Meyer, J. \& Stott, R. (1993). (Red). Organizational Environments. Ritual and Rationality. Beverly Hills, CA: Sage.

Palm, G \& Skogersson, R. (2008). Hjältar, blåljus och säkerhet - konstruktionen av polisen $i$ nyhetsmedia, Rapport 001-2008. Växjö: Växjö Universitet. 
Powell, W. \& Dimmaggio, P. (1991). (Red). The New Institutionalism in Organizational Analysis. Chicago. University of Chicago Press

RiR (2010). Polisen brottförebyggande arbete - har ambitionerna uppnåtts? RiR 2010:23. Stockholm: Riksrevisionen.

Sundevall, D. (2008). Hanteraren: uppdrag: Infiltrera svensk maffia. Stockholm: Alberts Bonniers förlag.

Wierup, L. (2008). Infiltratören - den smutsigaste härvan inom svensk polis. Stockholm: Nordstedts.

Woxblom, C., Holgersson, S. \& Dolmén, L. (2008). Polisens sätt att genomföra och redovisa LAU-tester. En explorative studie av polisens trafiksäkerhetsarbete. Solna: Polishögskolan.

Zucker, L. (1977). The role of institutionalization in cultural persistence. American Sociological Review, 42 sid 726-743.

Ydén, K. (2008). »Kriget och karriärsystemet. Försvarsmaktens organiserande i fred«. Doktorsavhandling, Handelshögskolan. Göteborg. Göteborgs universitet. 